\title{
Understanding ageing: Biomedical and bioengineering approaches, the immunologic view
}

\author{
Matteo Bulati ${ }^{1}$, Mariavaleria Pellicanò ${ }^{1}$, Sonya Vasto ${ }^{1,2}$ and \\ Giuseppina Colonna-Romano*1
}

\author{
Address: ${ }^{1}$ Gruppo di Studio sull'immunosenescenza and Dipartimento di Biopatologia e Metodologie Biomediche, Università di Palermo, \\ Palermo, Italy and 'Unità Operativa di Immunoematologia e Medicina trasfusionale, Università di Palermo, Palermo, Italy \\ Email: Matteo Bulati - matteo.bulati@unipa.it; Mariavaleria Pellicanò - valinap@ hotmail.com; Sonya Vasto - s.vasto@unipa.it; \\ Giuseppina Colonna-Romano* - gcolonna@unipa.it \\ * Corresponding author
}

Published: 3 September 2008

Immunity \& Ageing 2008, 5:9 doi:10.1186/1742-4933-5-9

This article is available from: http://www.immunityageing.com/content/5/I/9

(c) 2008 Bulati et al; licensee BioMed Central Ltd.

This is an Open Access article distributed under the terms of the Creative Commons Attribution License (http://creativecommons.org/licenses/by/2.0), which permits unrestricted use, distribution, and reproduction in any medium, provided the original work is properly cited.
Received: 18 August 2008

Accepted: 3 September 2008

\begin{abstract}
During the past century, humans have gained more years of average life expectancy than in the last 10,000 years; we are now living in a rapidly ageing world. The sharp rise in life expectancy, coupled to a steady decline in birth rates in all developed countries, has led to an unprecedented demographic revolution characterized by an explosive growth in the number and proportion of older people. Ageing is a complex process that negatively impacts the development of the immune system and its ability to function. Progressive changes in the $T$ and B cell systems over the life span have a major impact on the capacity to respond to immune challenge. These cumulative ageassociated changes in immune competence are termed Immunosenescence: some immunological parameters are commonly notably reduced in the elderly and, reciprocally good function is tightly correlated to health status. Hence, a better understanding of Immunosenescence and the development of new strategies to counteract it are essential for improving the quality of life of the elderly population.
\end{abstract}

\section{Background}

The "Understanding Aging: Biomedical and Bioengineering Approaches" conference was held from June 27-29, 2008 at UCLA organized by Aubrey de Grey to discuss and talk about possible intervention in ageing.

During the past century, mankind has gained more years of average life expectancy than in the last 10,000 years. We are now living in a rapidly ageing world. The sharp rise in life expectancy, coupled to a steady decline in birth rates in all developed countries, has led to an unprecedented demographic revolution characterized by an explosive growth in the numbers and proportion of older persons.
Nowadays, people are living much longer than they used to and the longer they live, the longer their bodies are exposed to environmental factors which increase the risk of age-associated diseases. The reduction of the response to environmental stimuli is associated with an increased predisposition to illness and death. This progression causes a reduction of the response to environmental stimuli and, in general, is associated with an increased predisposition to illness and death. In Western countries, the mortality rate increases in people over 65 years, if compared with individuals between 25 and 44 years old, by 100 -fold for stroke, as well as chronic lung disease, 92fold for heart disease, 89-fold for pneumonia and influ- 
enza, 43-fold for cancer [1]. On the contrary, ageing in good condition seems directly correlated with a good functioning of the immune system, suggesting that there are genetic determinants of longevity in genes regulating the immune inflammatory response $[2,3]$.

In senescence alterations of innate and instructive immunity have been described. The modifications of the immune system in the elderly are generally evaluated as a deterioration of the immune system, this is the origin of the term immunosenescence. A good immune system in the elderly is tightly correlated to health status, and some immunological parameters are often notably reduced in the elderly. On the other hand infectious diseases, tumors, autoimmune phenomenona and inflammatory chronic diseases like atherosclerosis and Alzheimer's disease, are frequent in this phase of the life course [3-5].

A body of experimental and clinical evidence has suggested that the immune system is implicated, with a variable degree of importance, in almost all age related or associated diseases. Both innate and instructive immune systems are usually involved in the pathogenesis of these chronic diseases. However, innate immunity appears to be the prevalent mechanism driving tissue damages associated with different age-related diseases [6]. So, ageing is accompanied by an age-dependent up-regulation of the inflammatory response, due to the chronic antigenic stress that impinges throughout life upon innate immunity, and has potential implications for the onset of inflammatory diseases [7].

Here is an extract of the talks and posters presented:

\section{Mitochondrial damage}

Perturbation of mitochondrial $\mathrm{Fe}$ homeostasis cause a decline in mitochondrial function that causes neuromuscular degenerative disease and other tissue dysfunction. C. Leeuwenburgh suggested that mitochondrial non-heme Fe represents a potential novel target for targeted interventions to slow ageing (C. Leeuwenburgh, University of Florida, USA) [8].

\section{Micronutrient inadequacy}

It was proposed that inadequate micronutrient intake leads to metabolic modification that has long term consequences such as cancer (DNA damage), severe infection (immune dysfunction) and cognitive dysfunction and accelerated ageing (mitochondrial decay). Much evidence supports the idea that micronutrient shortage accelerate ageing (B.N. Ames, University of California, Berkeley, CA, USA) [9].

\section{Telomeres}

The shortening of telomeres is supposed to be the molecular clock of ageing; indeed there is a strong correlation between age and telomere length and shorter telomeres directly correspond to shorter human life expectancy. For this purpose, several biotech organizations have accepted the challenge of finding ways to prevent telomere shortening by transiently inducing the activity of telomerase (L.A. Briggs, Reno, NV, USA). Another research has shown that therapy acting on the catalytic component of human telomerase, such as TAT2, a small molecule telomerase activator, could stabilize the telomere length and retard the loss of the immune control over viral infection (R. Effros, UCLA, Los Angeles, CA, USA) [10].

\section{Immunological Point of view}

On the immunological side Dr Z. Cui has shown that cancer cells in vitro could be killed by the effector cells of the innate immune system such as macrophages and neutrophils. A similar activity was discovered in some healthy people concerning granulocytes and monocytes (Z. Cui, Winston-Salem, NC, USA) [11].

According to the fact that the immune system plays an important role in ageing, the group of Prof. C. Caruso, actively involved in immunosenescence studies [2-5], has demonstrated that $B$ naïve lymphocytes, are increased in the offspring of healthy old centenarians. It has been demonstrated that the children of centenarians, who are in their 70s and 80s, have a survival advantage when compared with control subject of the same age range whose parents died at an average life expectancy [3]. The main lymphocyte differences observed between the two groups concern B cells. Indeed naïve B cells are more abundant as well as double negative $\mathrm{B}$ cells in centenarian children. These data are similar to that found in previously experiment on young subjects. So, B cell compartment of the offspring of centenarians seems to be more similar to that of young respect to the old one (S. Vasto, University of Palermo, Italy) [12].

It is well known that change in immune function are hallmarks of ageing and the group of Dr. A. Agrawal (University of California, Irvine, CA, USA) has shown that the reactivity of dendritic cells to self-antigens can be characteristic of ageing features. Furthermore, this over-reactivity induces lymphocyte $\mathrm{T}$ proliferation with subsequent higher risk of autoimmune diseases [13].

Interestingly, Effros's group suggests a possible involvement of hyper-activated $\mathrm{T}$ cells in bone loss associated with vascular disease in aged mice. The increased proportion of CD8 T cells lacking expression of the co-stimulatory receptor $\mathrm{CD} 28$ leads to decreased vaccine responsiveness and early mortality [14]. ST Parish found 
that loss of CD28 expression is caused by increased Caspase- 3 activity that can be induced by Tumor necrosis factor-alpha and suggested possible strategies for retarding the generation of senescent CD8 T cells during ageing (L.S. Graham, UCLA, Los Angeles, CA, USA).

\section{Conclusion}

Ageing is a complex process that negatively impacts the development of the immune system and its ability to function. Progressive changes in the T and B cell systems over the life span have a major impact on the capacity to respond to immune challenge. These cumulative ageassociated changes in immune competence are termed immunosenescence. A better understanding of immunosenescence and the development of new strategies to counteract it are essential for improving the quality of life of the elderly population [5]

\section{Competing interests}

The authors declare that they have no competing interests.

\section{Authors' contributions}

All authors contributed equally to the paper and read and approved the final manuscript

\section{Acknowledgements}

The authors thank Dr. A. De Grey (Methuselah Foundation, UK) and Prof. C. Caruso (University of Palermo, I) for revising critically the manuscript. Original work of Palermo's group was supported by Italian Ministry of University and Research PRIN 2006 Project to C. Caruso.

\section{References}

I. Troen BR: The biology of ageing. Mt Sinai J Med 2003, 70:3-22.

2. Candore G, Colonna-Romano G, Balistreri CR, Di Carlo D, Grimaldi MP, Listì F, Nuzzo D, Vasto S, Lio D, Caruso C: Biology of longevity: role of the innate immune system. Rejuvenation Res 2006, 9:143-8.

3. Franceschi C, Motta L, Motta M, Malaguarnera M, Capri M, Vasto S, Candore G, Caruso C, IMUSCE: The extreme longevity: the state of the art in Italy. Exp Gerontol 2008, 43:45-52.

4. Vasto S, Caruso C: Immunity \& Ageing: a new journal looking at ageing from an immunological point of view. Immun Ageing 2000, I:I.

5. Candore G, Balistreri CR, Colonna-Romano G, Grimaldi MP, Lio D, Listi' F, Scola L, Vasto S, Caruso C: Immunosenescence and antiimmunosenescence therapies: the case of probiotics. Rejuvenation Res 2008, I I:425-32.

6. Franceschi $C$, Bonafè $M$, Valensin $S$, Olivieri $F$, De Luca M, Ottaviani $\mathrm{E}$, De Benedictis G: Inflamm-ageing. An evolutionary perspective on immunosenescence. Ann N Y Acad Sci 2000, 908:244-54.

7. Vasto S, Candore G, Balistreri CR, Caruso M, Colonna-Romano G, Grimaldi MP, Listi F, Nuzzo D, Lio D, Caruso C: Inflammatory networks in ageing, age-related diseases and longevity. Mech Ageing Dev 2007, | 28:83-9|.

8. Hofer T, Marzetti E, Xu J, Seo AY, Gulec S, Knutson MD, Leeuwenburgh $C$, Dupont-Versteegden EE: Increased iron content and RNA oxidative damage in skeletal muscle with ageing and disuse atrophy. Exp Gerontol 2008, 43:563-70.

9. McCann JC, Ames BN: Is there convincing biological or behavioral evidence linking vitamin $D$ deficiency to brain dysfunction. FASEB J 2008, 22:982-100I.

10. Effros RB, Austad S, Blau H, Chesselet MF, Ingram D, Johnson TE, Kaeberlein M, Lundblad V, McCarter R, McElhaney J, Saag M: The biological sciences section program at the 60th Annual
Meeting of the Gerontological Society of America. J Gerontol A Biol Sci Med Sci 2008, 63:33I-7.

II. Hicks AM, Riedlinger G, Willingham MC, Alexander-Miller MA, Von Kap-Herr C, Pettenati MJ, Sanders AM, Weir HM, Du W, Kim J, Simpson AJ, Old LJ, Cui Z: Transferable anticancer innate immunity in spontaneous regression/complete resistance mice. Proc Natl Acad Sci USA 2006, 103:7753-8.

12. Colonna-Romano G, Bulati M, Aquino A, Vitello S, Lio D, Candore G, Caruso C: B cell immunosenescence in the elderly and in centenarians. Rejuvenation Res 2008, I I:433-9.

13. Agrawal A, Agrawal S, Tay J, Gupta S: Biology of dendritic cells in ageing. J Clin Immunol 2008, 28: 14-20.

14. Effros RB: Role of T lymphocyte replicative senescence in vaccine efficacy. Vaccine 2007, 25:599-604.
Publish with Biomed Central and every scientist can read your work free of charge

"BioMed Central will be the most significant development for disseminating the results of biomedical research in our lifetime. "

Sir Paul Nurse, Cancer Research UK

Your research papers will be:

- available free of charge to the entire biomedical community

- peer reviewed and published immediately upon acceptance

- cited in PubMed and archived on PubMed Central

- yours - you keep the copyright 